\title{
Bureaucratie en bureaucratisering : een theoretische en praktische verkenning van recente ontwikkelingen in de publieke sector en de particuliere sector
}

Citation for published version (APA):

van Mierlo, J. G. A. (1995). Bureaucratie en bureaucratisering : een theoretische en praktische verkenning van recente ontwikkelingen in de publieke sector en de particuliere sector. METEOR, Maastricht University School of Business and Economics. METEOR Research Memorandum No. 016 https://doi.org/10.26481/umamet.1995016

Document status and date:

Published: 01/01/1995

DOI:

10.26481/umamet.1995016

Document Version:

Publisher's PDF, also known as Version of record

Please check the document version of this publication:

- A submitted manuscript is the version of the article upon submission and before peer-review. There can be important differences between the submitted version and the official published version of record.

People interested in the research are advised to contact the author for the final version of the publication, or visit the DOI to the publisher's website.

- The final author version and the galley proof are versions of the publication after peer review.

- The final published version features the final layout of the paper including the volume, issue and page numbers.

Link to publication

\footnotetext{
General rights rights.

- You may freely distribute the URL identifying the publication in the public portal. please follow below link for the End User Agreement:

www.umlib.nl/taverne-license

Take down policy

If you believe that this document breaches copyright please contact us at:

repository@maastrichtuniversity.nl

providing details and we will investigate your claim.
}

Copyright and moral rights for the publications made accessible in the public portal are retained by the authors and/or other copyright owners and it is a condition of accessing publications that users recognise and abide by the legal requirements associated with these

- Users may download and print one copy of any publication from the public portal for the purpose of private study or research.

- You may not further distribute the material or use it for any profit-making activity or commercial gain

If the publication is distributed under the terms of Article $25 \mathrm{fa}$ of the Dutch Copyright Act, indicated by the "Taverne" license above, 


\title{
BUREAUCRATIE EN BUREAUCRATISERING \\ Een Theoretische en Praktische Verkenning van Recente Ontwikkelingen in de Publieke Sector en de Particuliere Sector
}

\author{
Hoofdstuk 4.5/D0500 voor \\ Besturen en Innovatie: \\ Handboek voor Bestuurders en Managers \\ Redactie: Prof dr J.M.H.J. Hemels en mr W.L.A. van Tuyll van Serooskerken \\ Uitgeverij Bohn, Stafleu en Van Loghum, Houten 1995
}

\author{
Dr J.G.A. van Mierlo \\ Universitair Hoofddocent Openbare Financiën/ \\ Economie van de Publieke Sector \\ Vakgroep Algemene Economie \\ Faculteit der Economische Wetenschappen \\ Rijksuniversiteit Limburg \\ Postbus 616 \\ 6200 MD Maastricht
}

Eerste Versie

September 1995 


\section{Samenvatting}

\section{Bureaucratie en Bureaucratisering. Een Theoretische en Praktische Verkenning van Recente Ontwikkelingen in de Publieke Sector en de Particuliere Sector}

\section{J.G.A. van Mierlo}

Bureaucratie en bureaucratisering zijn verschijnselen waardoor zowel moderne overheidsorganisaties als moderne ondernemingen worden geplaagd. Aan de bureaucratische organisatievorm kleven zowel voordelen als nadelen. De nadelen ervan worden in de moderne samenleving echter steeds groter. In dit research memorandum worden de begrippen bureaucratie en bureaucratisering aan een kritische theoretische en empirische analyse onderworpen. Daarbij wordt een onderscheid gemaakt tussen de organisatiestructuur en de organisatiecultuur van de bureaucratie.

De theoretische inzichten worden getoetst aan de ontwikkelingen in de bureaucratiepraktijk van overheid en onderneming. Het blijkt dat zowel overheden als ondernemingen proberen de voortschrijdende bureaucratisering tegen te gaan. Daartoe hebben ondernemingen reeds in de jaren zeventig het initiatief genomen, terwijl overheden pas in de jaren tachtig daartoe overgingen. Dat ondernemingen meer succes zouden hebben in hun strijd tegen bureaucratisme dan overheden, berust meer op speculaties en vooroordelen dan op de feiten uit empirisch onderzoek.

\section{Summary}

Bureaucracy and Bureaucratisation.

A Theoretical and Practical Exploration of Recent Developments in the Public Sector and the Private Sector

\section{J.G.A. van Mierlo}

Bureaucracy and bureaucratisation are phenomena which trouble modern government organisations as well as modern private firms. The bureaucratic organisation has both advantages and disadvantages, In modern society, the benefits of bureaucratic organisations are increasingly outweighed by the costs. and costs. In this research memorandum, the concepts of bureaucracy and bureaucratisation are subjected to a critical theoretical and empirical analysis. A distinction is made between the organisational structure and the organisational culture of bureaucracy.

Theoretical knowledge about bureaucracy is confronted with recent developments in the bureaucratic practice of government and business organisations. Government as well as business have developed policies and strategies against bureaucracy. Business already started with this in the early seventies, whereas governments followed as late as in the nineteen eighties. The opinion that business organisations have succeeded much better in fighting bureaucracy and bureaucratisation than government organisations, is more based on speculation and prejudice than on the results of empirical research. 


\section{Inhoud}

Samenvatting

1. Inleiding 1

2. Enkele centrale begrippen 2

2.1 Bureaucratie 2

2.2 Organisatiecultuur 4

3. Bureaucratietheorie 5

3.1 De sociologische bureaucratiebenadering 5

3.2 De psychologische bureaucratiebenadering 7

3.3 De politicologische bureaucratiebenadering $\quad 8$

3.4 De economische bureaucratiebenadering 9

3.5 Voorlopige conclusie $\quad 10$

4. Theorie van de organisatiecultuur 11

5. Veranderingen in de overheidssector $\quad 12$

6. Veranderingen in de bedrijvensector

7. 'Corporate culture'

8. Conclusie 18

$\begin{array}{ll}\text { Literatuur } & 19\end{array}$ 


\section{Inleiding}

In dit hoofdstuk worden de verschijnselen bureaucratie en bureaucratisering aan een kritische analyse onderworpen (zie ook Baakman en Van Mierlo, 1991: pp. 102-128). Zowel overheidsorganisaties als bedrijfsorganisaties kennen een bureaucratische organisatiestructuur. Wanneer de organisatiestructuur bureaucratischer wordt, is sprake van bureaucratisering. De bekende organisatiekundige Mintzberg (1979 en 1983) heeft ideaaltypen van organisaties ontwikkeld. Twee daarvan dragen een label waarin de term bureaucratie voorkomt (de 'professionele bureaucratie' en de 'machine bureaucratie'). Een derde ideaaltype van Mintzberg, de 'gedivisionaliseerde organisatie', wordt permanent bedreigd door een eraan inherente bureaucratiseringstendens (zie meer uitgebreid over de theorie van Mintzberg in de context van overheid en onderneming Baakman en Van Mierlo, 1991: pp. 81-101). Over het algemeen bureaucratiseren professionele organisaties als zij worden blootgesteld aan (een teveel aan) externe controle. Die algemene bureaucratiseringstendens is van belang voor het functioneren van zowel overheden als ondernemingen. Preciezer uitgedrukt gaat het bij bureaucratisering om een ontwikkeling in de richting van wat Mintzberg een machine bureaucratie noemt.

De meerduidigheid in het gebruik van de term bureaucratie is historisch gezien goed te verklaren. Het begrip is immers veel ouder dan het werk van Mintzberg. Etymologisch is het woord een samentrekking van het Oudgriekse kratos, dat onder meer 'sterkte' en 'heerschappij' betekent, met het Franse bureau, dat zowel op een schrijftafel als op een kantoor kan slaan. Oorspronkelijk duidt het woord dus op een (be)heersvorm. De eerste bureaucratieën waren overheidsorganisaties. De term kwam in zwang om een nieuw maatschappelijk verschijnsel aan te kunnen duiden: een overheid, nog veelal gepersonifieerd door een vorst, die in het dagelijks leven haar heerschappij minder via haar zwaardmacht gestalte ging geven, maar veel meer gebruik ging maken van voorschriften en papier, van klerken en schrijvers in grote kantoorzalen. Beeldend uitgedrukt kwam het bureau in de plaats van het kasteel en de ganzeveer in de plaats van het zwaard als de meest opvallende instrumenten waarmee de staatsmacht werd uitgeoefend. Onder de talloze toeristen die jaarlijks Florence bezoeken en zich vergapen aan schilderijen en tekeningen die zijn tentoongesteld in de rond 1570 onder Cosimo 1 de Medici gebouwde prachtige Uffizi (letterlijk: kantoren), zullen er maar weinig zijn die beseffen dat het gebouwencomplex waarin zij rondlopen een vroege en monumentale uitdrukking in steen is van die langzaam veranderende wijze van beheersen en beheren door de overheid.

Bij de ondernemingen kwamen zulke bureaucratische tempels pas veel later in zwang. Bedrijven waren in die dagen nog klein en ambachtelijk en bestonden doorgaans uit niet veel meer dan een meester en enkele gezellen. De ontwikkeling tot grote produktieorganisaties die van achter het bureau worden beheerst, kwam later op in samenhang met de Industriële Revolutie.

De wetenschappelijke theorievorming over het verschijnsel begon nog weer later: eigenlijk goed bij Max Weber, en dan zijn wij al aan het einde van de negentiende eeuw. In die theorievorming kwam de term bureaucratie uiteindelijk te staan voor een specifieker verschijnsel, namelijk een bepaalde wijze van organiseren. Met die wetenschappelijke opvattingen van en aandacht voor de bureaucratische wijze van organiseren houden wij ons in dit hoofdstuk bezig.

Het hoofdstuk is als volgt opgebouwd. In de volgende paragraaf wordt dieper ingegaan op een aantal begrippen uit de organisatietheorie, die voor het onderwerp van dit hoofdstuk van belang zijn. Het gaat daarbij vooral om het bureaucratiebegrip en in samenhang daarmee om het begrip organisatiecultuur. In de derde paragraaf wordt in kort bestek een overzicht gegeven van enkele wetenschappelijke bureaucratiebenaderingen. Datzelfde gebeurt in de vierde paragraaf ten aanzien van de theorie van de organisatiecultuur. Vervolgens wordt in de paragrafen vijf en zes ingegaan op veranderingen in de bureaucratie en in de organisatiecultuur die zich zowel bij overheden als bij bedrijven afspelen. Daarbij wordt expliciet een vergelijking tussen beide veranderingsprocessen gemaakt. In de zevende paragraaf wordt een en ander uitgediept aan de hand van empirisch onderzoek naar de 'corporate culture' van beide typen organisaties. Ten slotte worden enkele conclusies getrokken in paragraaf acht.

\section{Enkele centrale begrippen}

Elke organisatie heeft een structuur en een cultuur. De organisatiestructuur verwijst naar de formele verhoudingen tussen de leden van de organisatie, hun voorgeschreven handelingen ten opzichte van elkaar en de formele betrekkingen die zij onderling onderhouden. De organisatiecultuur heeft betrekking op de waarden, normen, opinies en opvattingen die door de leden van de organisatie worden gehuldigd 
en gedeeld. De term bureaucratie staat in de theorievorming voor een specifieke organisatiestructuur; maar ook wordt wel van een bureaucratische organisatiecultuur gesproken. Wij hebben het dan over een mentaliteit die bij die structuur past, over het in een organisatie geldende normen- en waardepatroon dat bij zo'n structuur hoort. Daarom worden beide termen hier kort behandeld. Eerst wordt ingegaan op het bureaucratiebegrip; daarna komt het begrip organisatiecultuur aan de orde.

\subsection{Bureaucratie}

De term bureaucratie is in de twintigste eeuw zozeer gemeengoed geworden, dat zij in een groot aantal betekenissen kan worden gebruikt. Sommige van die betekenissen sluiten elkaar zelfs uit. Albrow (1970: pp. 84-105) bijvoorbeeld noemt de volgende zeven moderne bureaucratiebetekenissen: bureaucratie als rationele organisatie (dus een bureaucratie als de meest rationele oplossing voor een organisatorisch probleem), als inefficiënte organisatie (hier is de term bijna een scheldwoord), als heerschappij van ambtenaren (dat is ook niet in ieders mond een compliment), als algemene aanduiding voor de overheidsadministratie, als ambtelijk beheer, als (synoniem voor) organisatie en als aanduiding van de macrostructuur van de moderne samenleving. Wij sluiten ons aan bij het in de bestuurs- en bedrijfswetenschappen dominante gebruik om bureaucratie te beschouwen als een formele organisatiestructuur die wordt gekenmerkt door onder meer differentiatie (arbeidsdeling), hiërarchische verhoudingen (iedereen heeft een chef) en positiebekleding op grond van deskundigheid. In de gespecialiseerde literatuur worden wel meer kenmerken genoemd, maar de bovenstaande zijn voorlopig als de belangrijkste te beschouwen. Bureaucratisering kan worden omschreven als het proces waardoor de interne structuur van een organisatie (en/of de omvattende externe structuur waarvan zij deel uitmaakt) in toenemende mate door deze kenmerken wordt gekarakteriseerd.

Daarmee zijn enkele van de betekenissen die door Albrow worden genoemd in dit verband minder relevant. Aan een synoniem voor het begrip organisatie bestaat niet veel behoefte; aan begrippen met een pejoratieve of lovende inhoud evenmin. In onze opvatting is dus sprake van een bureaucratie wanneer de betreffende organisatie aan een aantal objectieve kenmerken voldoet (zie Rosenthal e.a., 1987: pp. 47-48). Ten eerste moet er op elk organisatieniveau sprake zijn van een uitsplitsing van taken, ofwel specialisatie. Daarom kan een formele structuur, die beperkt blijft tot relaties tussen een groep en een door haar erkende leiding, nog niet als een bureaucratie worden beschouwd. Dan zou een elftal met een trainer immers ook een bureaucratie kunnen zijn. Ten tweede moeten er hoofdzakelijkerwijs hiërarchische relaties zijn. Er zijn immers ook formele structuren die niet door een overwegend hiërarchische coördinatie worden gekenmerkt. Wij hoeven maar te denken aan de overige ideaaltypen van Mintzberg. Sommige organisaties kennen een horizontale specialisatie en segmentering, professionele organisaties vertonen soms een platte structuur. Ten derde moet het deskundigheidsbeginsel bij de recrutering de doorslag geven. Het komt immers in tal van organisaties voor dat deskundigheid bij de toewijzing van taken alleen maar zijdelings meespeelt. Recrutering van leden heeft bij nogal wat organisaties plaats op grond van overwegingen die weinig met produktieprocessen (ondernemingen) of rationele beleidsprocessen (overheden) te maken hebben, zoals geboorte, raciale en etnische kenmerken, geslacht, persoonlijke relaties of politieke loyaliteit.

De grondlegger en theoreticus bij uitstek van de moderne bureaucratietheorie is de Duitse socioloog Max Weber. In de ideaaltypische omschrijvingen in zijn werk over de bureaucratie (Weber, 1972), zijn differentiatie, hiërarchie en recrutering op titel van deskundigheid echter niet de meest opvallende elementen. Dat komt mede omdat ook Weber verschillende soorten bureaucratie onderscheidt en hij structurele en culturele elementen of kenmerken door elkaar gebruikt in zijn ideaaltypen. Van de weberiaanse bureaucratietypen heeft het rationele type wel de meeste aandacht getrokken; de overige zijn min of meer uit het beeld verdwenen. Die rationele bureaucratie moet worden gezien in het perspectief van Weber's lange termijn-visie op de maatschappelijke ontwikkeling. Bureaucratie en bureaucratisering zag Weber als aspecten van het omvattende proces van rationalisering, van onttovering (Entzauberung) van de traditionele samenleving. In dat proces vervangen de rede en het streven naar doelmatigheid (Zweckrationalität) de hang naar traditie en het aanhangen van allerlei vormen van (bij)geloof. Concreter uitgedrukt houdt rationalisering van de samenleving in dit verband onder meer de opkomst van een geldeconomie, zakelijke verbintenissen op basis van vrijwillig afgesloten contracten en de opkomst van de rechtsstaat in. Weber noemt de volgende tien kenmerken van de rationele bureaucratie:

-Binnen hun werkverband zijn de functionarissen alleen onderworpen aan het gezag van de organisatieleiding. 
-Zij werken in een hiërarchische organisatiestructuur.

-Elk ambt is voorzien van een formeel vastgestelde competentiesfeer.

-Recrutering heeft primair plaats door vrije selectie.

-Deze vrije selectie voltrekt zich op grond van deskundigheid.

-De beloning is geldelijk (dat wil zeggen: niet in natura), is verbonden met de hiërarchische positie en is dus gelijk voor alle functionarissen die een gelijke rang innemen en dezelfde ervaring bezitten.

-De hoofdwerkzaamheden van de functionarissen bestaan uit die welke zij binnen de organisatie vervullen.

-Carrière wordt gemaakt op basis van senioriteit.

-De functionarissen doen hun werk met de middelen die door de organisatie ter beschikking worden gesteld.

-Er is in de organisatie sprake van een strikte en stelselmatige discipline en controle.

Twee dingen vallen in moderne ogen op aan deze opsomming. In de eerste plaats de vanzelfsprekendheid (en dus het weinig onderscheidende karakter) van veel van deze kenmerken. Wie brengt er nu nog zijn eigen gereedschap of schrijfmateriaal mee naar zijn werk, of wordt in natura betaald? Dat gebrek aan discriminerend vermogen is niet toe te schrijven aan een vermeende oppervlakkigheid van het werk van Weber, maar een aanwijzing voor de mate waarin de bureaucratisering van onze maatschappij als geheel sinds de dagen van Weber is voortgeschreden. In de tweede plaats ziet men dat het bureaucratiemodel van Weber zowel structurele alsook persoonsgebonden kenmerken bevat. Die persoonsgebonden kenmerken zijn uiting van een verinnerlijkte cultuur en komen met name naar voren in de gememoreerde discipline en controle. Hier ziet men ook de uitdrukking van het vermoeden van samenhang tussen de structuur en de cultuur van een organisatie. Formalisering en objectivering van de regelgeving leiden tot een bureaucratische handelwijze. De weberiaanse bureaucraat werkt volgens de regels, nauwkeurig en consistent. De cliënten worden door hem anoniem en zonder aanzien des persoons tegemoetgetreden. Die grondhouding komt voort uit een waardepatroon en is een cultuurkenmerk.

De belangrijkste plaats wordt in het model van Weber evenwel ingenomen door structuurkenmerken. Naar de mate waarin de genoemde kenmerken meer op de voorgrond treden, functioneert de bureaucratische organisatie in Weber's ogen rationeler. Er moet echter op gewezen worden dat de persoons- en de structuurkenmerken in verband met die rationalisatie in een wat merkwaardig onderling verband kunnen staan. Nauwkeurigheid, consistentie en handelen zonder aanzien des persoons kunnen op een gegeven moment de verwezenlijking van de formele organisatiedoeleinden immers verhinderen. Dat zijn de bekende bureaucratische uitwassen, en die zijn vanuit de organisatie als geheel bezien alles behalve doelrationeel. Wij spreken in dat verband wel van bureaucratisme (zie Hoogerwerf, 1985: pp. 47-61). Dat is een term met een negatieve lading, omdat zij op ontsporingen wijst. Anderzijds kunnen structurele kenmerken als differentiatie, hiërarchie en werving op grond van deskundigheid heel goed samengaan met onnauwkeurig, inconsistent of persoonlijk gekleurd gedrag van de bureaucraat.

Niet alleen tussen de structuur- en de persoonsgebonden elementen van het weberiaanse bureaucratiemodel kunnen spanningen bestaan, maar ook tussen de structuurelementen onderling. Rosenthal en de zijnen (1987: p. 49) wijzen er bijvoorbeeld op dat de hiërarchische structuur kan botsen met het deskundigheidsbeginsel. Zo kan de verhouding tussen discipline en deskundigheid onder druk worden gezet door technische ontwikkelingen die door de functionaris wel wordt bijgebeend maar door zijn chef niet. Men denke in dat verband aan de informatiseringsrevolutie! Ook kan professionalisering van de functionarissen problemen opleveren voor het opvolgen van opdrachten van boven, voor zover die tegen het waarden- en normenpatroon van de professie ingaan. Vooral in particuliere instellingen hebben zich in de eerste helft van de jaren zeventig scherpe conflicten voorgedaan tussen de nietprofessionele bestuurders van (veelal oorspronkelijk confessionele) bureaucratische organisaties en geprofessionaliseerde medewerkers. De Dennendal-affaire is daarvan een roemrucht voorbeeld; daarin werd uiteindelijk zelfs politieoptreden op het terrein van een zwakzinnigeninrichting niet geschuwd. Met Mintzberg in de hand kunnen wij dat soort processen benoemen: de 'operating core', de professionals, proberen het coördinatiemechanisme dat hen het beste past op te leggen aan de organisatie en raken daarbij in open conflict met de 'strategic apex', in dit geval het bestuur, dat daarover heel ander opvattingen heeft en de hiërarchische lijn volgen wil.

Het is hier niet de plaats om dieper in te gaan op de sterke en zwakke onderdelen van het weberiaanse bureaucratiebegrip. Wel kan worden vastgesteld dat het door Weber ontwikkelde bureaucratieconcept de opmaat is geweest voor de moderne bureaucratietheorie alsmede het hedendaagse 
bureaucratieonderzoek en bureaucratiedebat. Wij komen hierop later in dit hoofdstuk nog terug. Eerst dient het begrip organisatiecultuur nog aan de orde te komen.

\subsection{Organisatiecultuur}

Cultuur is bepalend voor het informele functioneren van een organisatie. In iedere organisatie is uiteraard sprake van cultuur, want al het menselijk handelen, ook het organisationele handelen, is doordrenkt met normen en waarden, riten en symbolen, met ingeburgerde wijzen van doen en met ideologie (Zijderveld, 1988: passim). De vraag is echter of een bepaalde configuratie daarvan kenmerkend voor het functioneren van de leden van juist deze concrete of specifieke soort organisatie. Is dat het geval, dan is er sprake van een eigen organisatiecultuur. Het begrip staat dan voor een groot aantal kenmerken die de (soort) organisatie en het functioneren van de leden binnen het organisationele verband typeren, maar waarvan de leden zich vaak nauwelijks bewust zijn. Wij kunnen denken aan een gemeenschappelijke, dat wil zeggen; gedeelde, mentaliteit, een gemeenschappelijke visie op de organisatie en op de buitenwereld als omgeving van die organisatie en een gevoel van collectieve identiteit (Ringeling, 1985). Naar aspecten van het verschijnsel organisatiecultuur verwijzen ook in het dagelijks spraakgebruik andere concepten, zoals in group-gevoelens, esprit de corps, corporate culture en organisatiesfeer.

Zo'n eigen organisatiecultuur wordt niet van de ene op de andere dag tot stand gebracht of eigen gemaakt. In sommige organisaties kost het jaren om gemeenschappelijke waarden en normen, riten en symbolen te ontwikkelen dan wel nieuw toegetreden leden de bestaande te laten absorberen. Maar is er duidelijk sprake van een eigen, specifieke organisatiecultuur, dan trekt zij volgens Rosenthal en de zijnen (1987: p. 78) een scherpe scheidslijn tussen degenen die tot de organisatie behoren en degenen die daarbuiten staan. Het is overigens de vraag deze opvatting niet te nauw aansluit bij het specifiekere begrip 'corporate culture', maar daarover volgt later meer. Volgens deze auteurs kan een analyse van de organisatiecultuur en de invloed daarvan op de organisatie vaak ook met betrekking tot onderdelen van een organisatie, zoals divisies, afdelingen en bureaus, worden gemaakt. Het gaat dan over organisatiesubculturen. Wanneer verschillende subculturen binnen één organisatie naast elkaar bestaan, roept dat echter vragen op over de effectiviteit van de betreffende organisatie in zijn geheel. Daarom is het in voorkomende gevallen altijd verstandig de functie die de organisatiecultuur voor het management van de organisatie vervult, nader te analyseren. De bestaande cultuur kan immers eventueel worden gebruikt als management-instrument. Anderzijds kan men proberen organisatieproblemen op te lossen door de cultuur te veranderen. Dat laatste is echter een uiterst moeizaam (want van bovenaf nauwelijks beheersbaar) proces.

Beheersbaar of niet, de cultuur van een organisatie oefent zeker grote invloed uit op het functioneren ervan. Met name de organisatiecultuur die binnen het bedrijfsleven heerst is de laatste jaren sterk in de belangstelling gekomen. Vooral in de populaire managementboeken van Amerikaanse oorsprong wordt het bewerken van de organisatiecultuur aangeprezen als een wondermiddel voor het oplossen van bedrijfsproblemen en derhalve voor een gigantische economische expansie van het bedrijf. Het in meeslepende stijl geschreven In search of excellence van Peters en Waterman (1982, Nederlandse titel: Excellente ondernemingen) heeft in de jaren tachtig enorm bijgedragen tot een enorme populariteit van wat in wezen tamelijk alledaagse inzichten blijken te zijn. Zij infecteerden ook het denken over het functioneren van de overheid, bijvoorbeeld met concepten als zelfbeheer en contractmanagement. Wil dat enig effect sorteren, dan zal dat effect in hoofdzaak moeten worden bewerkstelligd via een cultuurverandering. Echte interne contracten en autonome eenheden stuiten immers op staatsrechtelijke grenzen. De ijveraars voor zelfbeheer hebben dat intuïtief goed begrepen en daarom contractmanagement en zelfbeheer in de geest van Peters en Waterman en het ruim-baan-voor-het-bedrijfsleven-ethos van de jaren tachtig aangeprezen als het 'recept voor een excellente overheid'.

\section{Bureaucratietheorie}

Hierboven is al gesteld dat Max Weber als de grondlegger van de moderne bureaucratietheorie kan worden beschouwd. Bureaucratie betekent letterlijk: 'heerschappij door ambtenaren'. Bureaucratie, in de meer neutrale betekenis van de 'organisatie van het overheidsbestuur', vormt ook een klassiek thema in de bestuurskunde (zie Ringeling, 1981: pp. 260-282; 1991: pp. 251-273). Een bonte rij bestuurskundigen heeft zich met dit verschijnsel bezig gehouden, ten eerste natuurlijk omdat de eerste bureaucratieën 
overheidsorganisaties waren. Maar vooral ook omdat de problematische aspecten van de 'bureaucratische organisatievorm' in toenemende mate door de expansie van de verzorgingsstaat en de daardoor uitdijende overheidsorganisaties aan het licht werden gebracht. De bureaucratische organisatievorm is echter niet alleen de kenmerkend voor de overheidssector, maar komt ook veel voor in de sector van het bedrijfsleven. Dat slaagt er echter beter in om de ook daar voorkomende bureaucratische uitwassen binnenskamers te houden dan het openbaar bestuur, dat immers in beginsel in volle openbaarheid moet werken.

De publikaties op dit gebied kunnen op vele manieren worden ingedeeld (zie bijvoorbeeld ook Van Mierlo, 1988a: pp. 230-231). De bestuurskunde is probleemgeoriënteerd en interdisciplinair. Er bestaat daarom niet zoiets als de bureaucratietheorie. In feite bestaan er verschillende, gedeeltelijk elkaar aanvullende maar gedeeltelijk ook met elkaar strijdige, bureaucratietheorieën. Zij kunnen, al naar gelang de disciplinaire invalshoek, worden ingedeeld in de sociologische benadering, de psychologische benadering, de politicologische benadering en de economische benadering.

\subsection{De sociologische bureaucratiebenadering}

De sociologische bureaucratiebenadering is direct gebaseerd op het pionierswerk dat door Weber is verricht. Ook leunt deze benadering sterk op de moderne organisatiesociologie. In de sociologische bureaucratiebenadering ligt de nadruk vooral op de organisatiestructuur van de bureaucratie. Daarbij gaat de aandacht primair uit naar de formele structuur, terwijl de informele aspecten van de bureaucratie slechts zijdelings aan de orde komen. De nadruk op de formele structuur wordt onder meer gelegd door de Scientific Management School, het Taylorisme en de Science of Administration-benadering (zie Rosenthal e.a., 1987: pp. 40-42).

De voornaamste auteurs van de sociologische bureaucratiebenadering zijn, naast Weber, Albrow en Mayntz, terwijl in Nederland Van Braam als de belangrijkste exponent van deze stroming kan worden gezien. In de sociologische benadering nemen niet alleen de structuurkenmerken van de bureaucratie een centrale plaats in, maar ook de structurele voorwaarden voor een effectieve en efficiënte organisatie. Daarmee komt de invloed van de organisatiestructuur op de beleidsuitvoering in de aandacht.

Volgens Van Braam (1986: pp. 377-382) is een bureaucratische organisatie in de eerste plaats een doelorganisatie: zij is opgericht ter verwezenlijking van bepaalde doeleinden. Maar er is meer. Deze doelorganisatie wordt gekenmerkt door bepaalde eigenschappen zoals omvang en complexiteit, structuur, regels en procedures, leiding en werkwijze. Vele van deze eigenschappen zijn in het voorgaande reeds aan de orde geweest.

In de moderne tijd hebben bureaucratische organisaties een enorme omvang en complexiteit aangenomen. Er is evenwel geen logische (dat wil zeggen: uit de theorie afleidbare), maar wel een empirische samenhang tussen bureaucratie, omvangrijke organisatie en complexiteit. Deze samenhang kan worden verklaard uit de toenemende complexiteit van de moderne samenleving na de Tweede Wereldoorlog en uit de groei van de verzorgingsstaat sindsdien. Processen van schaalvergroting, concentratie en centralisatie, formele standaardisatie en technologisering hebben het ontstaan van een omvangrijk bureaucratisch raderwerk bevorderd.

Dit raderwerk wordt gekenmerkt door een sterk gedifferentieerd stelsel van taak- en gezagsverdeling. De bureaucratische organisatie kent een gedifferentieerde functionele en hiërarchische structuur. De posities in een dergelijk structuur zijn piramidaal verdeeld: het aantal posities neemt af naarmate het gezags- of functieniveau hoger wordt. De organisatieregels en -procedures zijn in een bureaucratie sterk geformaliseerd. Deze regels en procedures zijn op schrift gesteld. Daarmee wordt bewerkstelligd dat ambtelijk handelen formeel handelen is binnen strikt formele bevoegdheden.

Het besturingsregime van bureaucratische organisaties is monocratisch en centralistisch: in beginsel is sprake van éénhoofdige leiding en de bevelvoering is verticaal en top-down'. Beleid, regels en bevelen komen van boven en beslissingen worden genomen op het hoogste competente gezagsniveau. Bovendien geldt eenheid van bevel: iedere ondergeschikte heeft slechts één chef. Als gevolg van deze kenmerken tendeert het bureaucratisch handelen volgens Van Braam naar relatieve traagheid van de besluitvorming, rolminimalisatie (de bureaucraat vraagt zich dan eerst af of een bepaalde handeling in zijn taakomschrijving staat en zo dat niet geval is, verwijst hij naar het volgende loket), routinematig en automatisch handelen en rigiditeit.

Deze bureaucratische organisatiekenmerken zijn reeds prominent aanwezig in het ideaaltypische bureaucratiemodel van Weber. In zijn model vormen zij een gesloten geheel van logische kenmerken van dit organisatietype. In de sociologische benadering zijn zij vervolgens gehanteerd als een 
onderzoekprogramma, waarvan de centrale vraagstelling luidde: zijn deze bureaucratiekenmerken ook in de praktijk van de bureaucratische organisatievorm aanwezig (en in welke mate en in welke combinatie)? Daarmee verschoof de aandacht naar de bureaucratie als empirisch verschijnsel. De antwoorden die op deze vraag werden geformuleerd, leidden al spoedig tot een tweede vraag: welke invloed wordt door de bureaucratische organisatiekenmerken uitgeoefend op de beleidsuitvoering door deze organisatie? Deze tweede vraag markeert een ingrijpende verandering in de bestuurskunde als wetenschap. In de jaren tachtig verschoof namelijk de aandacht van de inhoud van het overheidsbeleid naar de processen van uitvoering van dat beleid, naar de effecten ervan op de samenleving en de terugkoppeling van dit alles naar het politieke besluitvormingsproces over het beleid. In bestuurskundig jargon wordt dat uitvoeringsonderzoek implementatieonderzoek genoemd. De aandacht voor implementatie van beleid door bureaucratieën werd vooral geïnspireerd door het toenemende besef, dat aan de bureaucratische organisatievorm niet alleen voordelen kleven (die vooral door Weber zijn benadrukt: hij zag de bureaucratie immers als een doelrationele constructie), maar ook nadelen.

Van dat moderne beleidsuitvoerings- of implementatieonderzoek is de Duitse bestuurssociologe Renate Mayntz een belangrijke exponent (zie ook Maarse, 1988: pp. 377-393). Zij heeft zich met name bezig gehouden met het analyseren van de structurele voorwaarden voor een effectieve en efficiënte organisatie van de bureaucratie. Bij de analyse van deze structurele voorwaarden neemt het bureaucratiebegrip van Weber een voorname plaats in (zie Mayntz, 1968; Maarse, 1987). Haar speciale belangstelling gaat in dit verband uit naar de klassiek geworden kritiek op de bureaucratie als zou deze organisatiestructuur op gespannen voet staan met het democratisch ideaal. Voorts gaat haar aandacht uit naar het veronderstelde disfunctioneren van de bureaucratie vanuit het gezichtspunt van effectiviteit en efficiëntie van organisaties.

Daarmee is de aanzet gegeven tot de huidige twee zwaartepunten in de sociologische bureaucratiebenadering, te weten: de analyse van de voorwaarden voor een actief overheidsbeleid en de studie van de beleidsuitvoering. Daarbij is de aandacht verschoven van theorievorming naar empirisch onderzoek, waarbij in Nederland de laatste jaren vooral de nadruk ligt op uitvoeringsonderzoek.

\subsection{De psychologische bureaucratiebenadering}

De psychologische bureaucratiebenadering is gedeeltelijk ontstaan als reactie op de sociologische, structureel-functionalistische benadering van het bureaucratieverschijnsel. In de psychologische benadering wordt de nadruk vooral gelegd op de informele organisatieaspecten van de bureaucratie. Rosenthal e.a. (1987: pp. 72-75) stellen dat vooral de zogeheten Coöperatietheorie en de Participatieve Management School psychologische factoren in de organisatie centraal stellen. Bekende exponenten van de psychologische bureaucratiebenadering zijn bijvoorbeeld Edelman en Schein en in Nederland Vroom.

In deze benadering, die overigens ook door de cultuursociologie is geïnspireerd, staat de gedachte centraal, dat zingeving en symbolische interactie het functioneren van de bureaucratie bepalen (zie Frissen, 1987: pp. 404-405). In de bureaucratie domineert een bepaalde vorm van rationaliteit, namelijk de functionele. Als gevolg daarvan wordt in de bureaucratie veel waarde gehecht aan ordelijkheid, aan overzichtelijke indelingen, aan voorspelbaarheid en beheersbaarheid. Rechtsgelijkheid, dat wil zeggen gelijke gevallen gelijk behandelen, is een belangrijke norm. Daarom moet, om die regelmaat te garanderen, voor bijna alles een regel gemaakt worden. Deze waarden en normen kenmerken ook het optreden van de bureaucratie naar buiten. Ten aanzien van de werkelijkheid wordt een beeld gehanteerd dat de bureaucratie van zich zelf heeft. De structurele kenmerken van de bureaucratie worden opgelegd aan de omgeving waarin zij opereert. Op deze wijze tracht de bureaucratie de werkelijkheid tot een voor haar zinvol symbolisch geheel te maken. Daarmee betreden wij het terrein van de organisatiecultuur, waarover in de volgende paragraaf meer.

Een tweede thematiek die in de psychologische bureaucratiebenadering centraal staat, betreft de gedragswijzen van ambtenaren. Dit gedrag wordt door een groot aantal factoren bepaald, zoals de formele en informele rolverwachtingen, de karaktereigenschappen van de actoren, persoonlijke belangen en groepsbelangen, verschillende omgevingsinvloeden, organisatorische factoren, enzovoorts. In de psychologische benadering worden uiteraard vooral de psychologische gedragsfactoren benadrukt.

Door deze factoren vertoont het ambtelijk gedrag een grote mate van variëteit en verscheidenheid. Bureaucratisch gedrag kan daarom functioneel zijn maar ook disfunctioneel, afhankelijk van de vraag of de (officiële) organisatiedoeleinden daardoor worden verwezenlijkt of juist belemmerd. De eerder al genoemde Van Braam (1986: pp. 221-227) gaat vooral in op disfunctioneel gedrag, dat leidt 
tot formalisme, paperasserie ('red tape') en bureaucratisme. Het zijn juist deze uitwassen die het stereotiepe beeld dat de goegemeente nog steeds heeft van het ambtelijk apparaat, in de hand hebben gewerkt. Globaal bestaan er twee stereotypen: dat van de almachtige en eigengereide ambtenaar aan wiens willekeur de burger is overgeleverd, en dat van de machteloze en passieve ambtenaar die ook maar doet wat hem van hogerhand is opgedragen. Dit verhelderend onderscheid is bijvoorbeeld gemaakt door Ringeling in zijn boek over de beleidsvrijheid van ambtenaren uit 1978 .

De psychologische bureaucratiebenadering heeft vooral licht geworpen op de afstand die kan bestaan tussen de formele en de informele structuur van de bureaucratische organisatie. De afstand tussen beide structuren kan snel leiden tot een spanningsverhouding. Deze spanning kan in theorie worden opgelost door vanuit de formele structuur te zoeken naar een aanpassing aan de ontstane situatie, dan wel de informele structuur zelf te formaliseren.

\subsection{De politicologische bureaucratiebenadering}

De politicologie analyseert met behulp van politicologische begrippen en theorieën de structuren en processen die zich in het openbaar bestuur afspelen (Rosenthal e.a., 1987: p. 29). Zowel de interne als de externe facetten van het openbaar bestuur worden onderzocht. Met betrekking tot de interne facetten wordt veel aandacht besteed aan de relatie tussen gezagsdragers en ambtenaren en aan de zogeheten bureau-politieke aspecten van de bestuurlijke organisatie, waarover verderop meer. De politicologische analyse van de externe werking van het openbaar bestuur betreft de relatie tussen het openbaar bestuur en zijn politieke omgeving. Daarbij wordt met name ingegaan op de verhouding tot het parlement, de politieke partijen, pressie- en actiegroepen en op de positie van het openbaar bestuur in de internationale politieke context.

In de politicologie worden de organisatie en het beleid van de overheid geanalyseerd als onderdelen van het politieke proces. In het bijzonder wordt de bureaucratische organisatie van de overheid in deze benadering bezien vanuit een bureaupolitiek perspectief. In dit perspectief staan machtsen invloedsprocessen in de bureaucratie centraal. Het model van de bureaucratische politiek, ofwel bureaupolitiek, is oorspronkelijk ontwikkeld door Allison (1971) en door hem te zamen met twee andere modellen (het rationele actor-model en het organisatiemodel) toegepast op de Cuba-crisis van 1962. Halperin (1974) heeft dit model gebruikt in zijn analyse van de Amerikaanse buitenlandse politiek. In zijn Leidse oratie heeft Rosenthal (1988) dit model kritisch besproken en vervolgens gehanteerd in zijn analyse van de Paspoort-affaire. Zijn bevindingen vatten wij als volgt samen (zie ook Berg, 1975).

In het bureaupolitieke model van de bureaucratie staan concurrentie en rivaliteit tussen onderdelen van de overheidsorganisatie centraal. Het bureaupolitieke model staat tegenover modellen waarin eenheidssymbolen als de staat en de overheid de boventoon voeren. Het model kan worden gebruikt ten behoeve van een empirische beschrijving van de overheidsorganisatie (hoe werkt de bureaucratie feitelijk?), maar ook ten behoeve van een normatieve prescriptie daarvan (hoe zou de bureaucratie idealiter moeten werken?). Onder meer omdat de descriptieve toepassing en het prescriptieve gebruik van het bureaupolitieke model nogal eens door elkaar lopen, is dit model onder bestuurskundigen niet onomstreden.

Op grond van zijn theoretische verkenning komt Rosenthal tot de volgende herformulering van het bureaupolitieke model van de overheidsbureaucratie. Ten eerste is er sprake van veel spelers. Het gaat niet alleen om bureaus en bureaucraten; wel wordt specifieke aandacht besteed aan de rol die bureaus en bureaucraten spelen. Interorganisatorische verhoudingen en netwerken, waaronder die van binnenlands bestuur, kunnen in bureaupolitieke analyses worden meegenomen. Ten tweede zijn er uiteenlopende belangen van de spelers die empirisch kunnen worden vastgesteld. Bovendien worden ook andere belangen dan het algemeen belang nagestreefd. Voorts heeft geen van de spelers een overheersende invloed, maar wel is de invloed van bureaus en bureaucraten groter dan de normatieve leer van de democratische politiek bepaalt. Ten vierde worden compromisbeslissingen genomen. Compromisvorming kan worden vergemakkelijkt door het algemeen belang, maar verschillende interpretaties van het algemeen belang kunnen het bereiken van een compromis tegenwerken. Ten slotte is er ruimte tussen besluitvorming en uitvoering van beslissingen. Die ruimte is groter naarmate meer categorieën spelers bij de besluitvorming zijn betrokken en het beslissingsproces langer duurt.

Voorbeelden van bureaupolitiek, die zich laten analyseren met behulp van de politicologische bureaucratiebenadering, worden in de Nederlandse situatie door bestuurskundigen vooral gezocht in de verhoudingen tussen twee of meer departementen die bij een beleidsonderdeel zijn betrokken. Klassiek is de strijd tussen Economische Zaken en Buitenlandse Zaken over de verantwoordelijkheid 
voor het buitenlandse economische beleid. Rosenthal past deze benadering toe op de paspoortaffaire die zich in de tweede helft van de jaren tachtig heeft afgespeeld. Hij komt tot de conclusie dat met dit model een zeer verhelderend inzicht kan worden verkregen in de strijd die is gevoerd tussen diverse onderdelen van de overheidsbureaucratie over de invoering van het nieuwe paspoort. Er waren veel spelers bij betrokken maar geen ervan had een doorslaggevende invloed. Er was sprake van tegengestelde belangen tussen spelers. Er werden compromisbeslissingen genomen en er was een grote ruimte tussen beslissing en uitvoering.

Niet alleen kan de politicologische benadering een helder licht werpen op het bureaupolitieke functioneren van de overheidsbureaucratie. Rosenthal laat in zijn hantering van dit model ook zien, dat er in het Nederlandse politieke bestel krachten werkzaam zijn als gevolg waarvan de voordelen van bureaupolitiek - een systeem van wederzijdse checks and balances - worden overtroffen door de nadelen daarvan: blokkering van de besluitvorming en immobilisme. Rosenthal noemt deze verwording van het bureaupolitieke model bureaupolitisme. Besluitvorming over overheidsbeleid op verzuilingsgrondslag zou steeds meer plaats maken voor besluitvorming daarover volgens het model van bureaupolitisme. Omdat degelijk empirisch onderzoek ontbreekt, draagt deze conclusie een speculatief karakter. Het is echter de verdienste van de politicologische benadering dat naast de positieve kenmerken van het bureaupolitieke model ook aandacht wordt gevraagd voor de schaduwzijde ervan in de vorm van bureaupolitisme.

\subsection{De economische bureaucratiebenadering}

De economische bureaucratiebenadering vormt de jongste variant van de bureaucratietheorieën. Deze economische benadering is ontstaan als onderdeel van de public choice-stroming in de politicologie en economie (zie Van Mierlo, 1984; Van Mierlo, 1988a). De grondlegger van de economische bureaucratiebenadering is Downs (1967), terwijl ook Niskanen (1971) een belangrijke, meer wiskundigmodelmatige bijdrage heeft geleverd.

In de economische bureaucratiebenadering wordt gebruikt gemaakt van het micro-economische paradigma van de welvaartstheorie (zie ook Van en Doel en Van Velthoven, 1991: hoofdstuk 6). Dit paradigma omvat onder meer de volgende kenmerken. In de eerste plaats wordt het model van de homo economicus gebruikt. men gaat ervan uit dat mensen ernaar streven hun nut te maximaliseren en zich in hun gedrag door dat streven laten leiden. Ten tweede wordt uitgegaan van het methodologisch individualisme en de atomistische organisatie-opvatting. Dat betekent dat de logic of institutions wordt geanalyseerd in termen van het gedrag van de personen door wie deze organisaties worden bevolkt: organisatiegedrag wordt dan opgevat als het resultaat van individuele menselijke gedragingen binnen de organisatie. Ten derde wordt uitgegaan van het postulaat van consumenten- en kiezerssoevereiniteit: de voorkeuren van de kiezers dienen maatgevend te zijn voor de vaststelling van het overheidsbeleid, zoals de voorkeuren van de consumenten het ijkpunt moeten zijn voor het ondernemingsbeleid. Ten slotte wordt de axiomatisch-deductieve methode gehanteerd. Dat wil zeggen dat uit deze en andere geformaliseerde abstracte aannames (axioma's) langs logische weg nieuwe uitspraken over de werkelijkheid worden afgeleid (gededuceerd). In het algemeen is in de sociale wetenschappen de empirisch-inductieve weg gebruikelijker. De route loopt dan van concreet naar abstract: men bestudeert bijvoorbeeld drie of vier concrete bureaucratische organisaties (empirie) om tot verderreikende theorie over het onderzochte verschijnsel in het algemeen te komen.

In een baanbrekende studie heeft Downs (1967) de aanzet gegeven tot wat nadien de 'economische theorie van de bureaucratie' is geworden (zie ook Van Mierlo, 1988a). In deze studie wordt het interne functioneren van ambtenaren in bureaucratische organisaties ontleed, of deze nu behoren tot de overheidssector of tot de bedrijfssector. Ambtenaren worden in de opvatting van Downs (evenals dat het geval is met politici) gedreven door motieven van eigenbelang (nutsmaximalisatie) ten aanzien van de baten die aan hun positie zijn verbonden. Die baten variëren naar gelang de positie die ambtenaren in de bureaucratie innemen en naar gelang de rolopvatting die zij vanuit hun karakterologische predispositie hanteren. Daartoe ontwikkelt hij een typologie van ambtelijke rolgedragingen, die uit de combinatie van structuurkenmerken van de bureaucratie (de sociologische bureaucratiebenadering!) en persoonskenmerken van de ambtenaren (de psychologische bureaucratiebenadering!) resulteren. Hij toont verder aan dat ambtenaren die door motieven van eigenbelang worden gedreven, onder bepaalde voorwaarden de maatschappelijke functie vervullen van bevrediging van de politieke vraag naar publieke goederen en diensten. 
Downs maakt hier niet het onderscheid tussen uiteindelijke motivatie en gedragsregulerende motivatie (waarover hieronder meer), wellicht omdat hij zulks niet nodig acht voor zijn analyse van het interne functioneren van ambtenaren in de bureaucratische overheidsorganisatie. Minstens zo belangrijk echter is het externe functioneren van ambtenaren, met name in hun betrekkingen met de politici. Niskanen (1971) heeft de verhouding tussen politici en ambtenaren in een representatieve democratie geanalyseerd met behulp van een wiskundig-economisch model, waarin de politici publieke goederen en diensten vragen en daartoe aan ambtenaren produktieopdrachten verstrekken en waarin ambtenaren publieke goederen en diensten aan politici aanbieden in ruil voor begrotingsgelden die hen ter beschikking worden gesteld. De verhouding tussen politici en ambtenaren wordt door Niskanen voorgesteld als een bilateraal monopolie, waarbinnen de ambtenaren als gevolg van de structuurkenmerken van de bureaucratie de overhand hebben. Het resultaat van deze analyse is bureaucratische overproduktie vanuit het gezichtspunt van het collectieve welvaartsoptimum van de burgers. door de werking van de bureaucratie zou de overheid structureel meer goederen en diensten produceren (en dus geld uitgeven en dus ook belasting heffen) dan voor een optimale welvaart voor de burgers nodig is. In het geval van een onderneming zou een goed werkende markt dat verhinderen.

Op deze wijze verbindt Niskanen de omvang van de publieke sector aan het functioneren van ambtenaren in bureaucratische overheidsorganisaties. Hij heeft bovendien de logische analyse van ambtelijk gedrag van Downs voortgezet door niet alleen het interne functioneren van ambtenaren maar ook hun externe functioneren in zijn analyse op te nemen. Sindsdien is in de economische bureaucratiebenadering de relatie tussen de gedragingen van politici en van ambtenaren in het kader van een representatieve democratie aan de ene kant en de omvang van de publieke sector in een gemengde volkshuishouding aan de andere kant, een aanhoudend onderwerp van nieuwe theorievorming en empirisch onderzoek (zie bijvoorbeeld het tijdschrift Public Choice). De resultaten ervan lijken in Nederland echter meer door te sijpelen naar de leer der openbare financiën, die gestimuleerd door ontwikkelingen in de moderne welvaartstheorie in de jaren tachtig een enorme vernieuwing heeft ondergaan (zie bijvoorbeeld Wolfson, 1988), dan naar de bestuurskunde.

De economische bureaucratiebenadering heeft sterke theoretische punten. Ten eerste worden inzichten uit de sociologische bureaucratiebenadering (structuurkenmerken) gecombineerd met die uit de psychologische bureaucratiebenadering (persoonlijkheidskenmerken). Verder wordt benadrukt dat ambtenaren niet louter en alleen worden gedreven door het streven om het algemeen belang, respectievelijk het belang van hun organisatie of diens cliëntèle te dienen, maar ook door motieven van eigenbelang, zoals overigens ook wordt gesteld in de politicologische benadering. Dat betekent dat maximalisatie van de doelstellingsfunctie van de bureaucraat in conflict kan komen met het dienen van de publieke zaak door ambtenaren. Daardoor komt de bureaucratische (overheids)organisatie in een geheel ander daglicht te staan dan in de oorspronkelijke, weberiaanse opvatting van het ambtelijk apparaat als een onpartijdige dienaar van het algemeen belang.

De derde verdienste van de economische benadering betreft de aanzet die zij heeft gegeven tot verdergaande theorievorming over het verband tussen ambtelijk gedrag in bureaucratische organisaties en diverse problemen van de publieke sector (omvang, beheersbaarheid, democratische controle). De nadruk ligt op verfijning van de modelbouw, maar daarin is tevens de zwakte van deze benadering gelegen. Empirisch onderzoek, waarin de hypothesen die uit de economische theorie van de bureaucratie kunnen worden afgeleid aan een lakmoesproef worden onderworpen, is tot dusver schaars gebleven. Dat geeft aan de economische bureaucratiebenadering nog steeds een wat speculatief karakter (zie ook Van Mierlo, 1988a).

\subsection{Voorlopige conclusie}

De verschillende bureaucratiebenaderingen zijn disciplinair verankerd. Elk van de vier benaderingen is gebaseerd op een ander wetenschappelijk paradigma. Dat betekent dat de verschillende benaderingen elkaar niet uitsluiten maar aanvullen. Elke bureaucratiebenadering legt de nadruk op een ander aspect van de bureaucratische organisatievorm. Te zamen leveren de vier behandelde benaderingen een wetenschappelijk totaalbeeld op van de bureaucratie als organisatie.

\section{Theorie van de organisatiecultuur}


In een overzichtsartikel stelt Frissen (1986: pp. 532-544) in navolging van Peters en Waterman (1982: p. 105), dat de organisatietheoretische belangstelling voor het verschijnsel organisatiecultuur tot modieuze proporties is uitgegroeid. Organisatiecultuur werd onder meer door de bestseller van Peters en Waterman een hit op de markt van de managementliteratuur. Die markt was overigens al bewerkt door boeken over de Japanse uitdaging, waarin de stelling werd verdedigd dat Japanse ondernemingen zo veel succes boeken vanwege hun culturele coherentie.

De conclusies in de hausse van organisatietheoretische literatuur over cultuur zijn volgens Frissen divers, maar het belang van de organisatiecultuur als zodanig, zowel in analytisch als in praktisch opzicht, wordt algemeen erkend. De economische ontwikkelingen in de tweede helft van de jaren zeventig (recessie en 'Japanse uitdaging') vormen een belangrijke achtergrond voor de inmiddels omvangrijke belangstelling voor het verschijnsel 'organisatiecultuur'. Als begrip krijgt organisatiecultuur pas bekendheid in de jaren tachtig, maar tot de organisatiecultuur worden ook verschijnselen gerekend die al veel langer voorwerp van studie zijn: ideologie, waarden, normen, ethiek, symbolen, leiderschapsen managementstijl (zie ook Lammers, 1983). De culturele factor neemt een specifieke positie in de organisatie in. De organisatorische positionering van de organisatiecultuur kan (in navolging van Frissen, 1986) worden gebruikt om vier benaderingen in de theorie van de organisatiecultuur te onderscheiden. Deze benaderingen zijn: cultuur als contingentiefactor, cultuur als subsysteem van een organisatie, cultuur als een aspectsysteem van een organisatie en de organisatie als cultureel fenomeen (zie meer uitgebreid Frissen, 1986: pp. 532-544).

Als contingentiefactor is de cultuur relevant voor het functioneren van de organisatie. Enerzijds gaat het om de maatschappelijke cultuur waarbinnen de organisatie functioneert, anderzijds om de culturele achtergrond van de leden van de organisatie. In deze opvatting zijn organisaties altijd ingebed in en deel van een specifieke maatschappelijke cultuur. Er kan sprake zijn van een gedifferentieerde maatschappelijke cultuur en de leden van de organisatie kunnen tot verschillende maatschappelijke subculturen behoren. De contingentietheorie benadrukt vooral het verband tussen maatschappelijke cultuur en functioneren van de organisatie, waarbij niet alleen adaptatie (aanpassing) maar ook anticipatie (vooruit lopen op) mogelijk zijn. Het verband tussen beide is vooral van belang in geval de organisatie in verschillende culturen opereert en haar leden uit die verschillende culturen recruteert, bijvoorbeeld multinationale ondernemingen (zie hiervoor meer uitgebreid bijvoorbeeld Hofstede, 1980; 1983) of supranationale overheden.

Als subsysteem wordt de cultuur als een afzonderlijk onderdeel van organisaties opgevat. In deze visie, die nauw met de vorige samenhangt, moet cultuur onderscheiden worden van andere subsystemen, zoals de structuur van de organisatie en de technologie die wordt gebruikt. De subsystemen hangen met elkaar samen, maar kunnen in beginsel los van elkaar worden geanalyseerd. Te zamen vormen de subsystemen de organisatie als entiteit. Peters en Waterman bijvoorbeeld (1982) stellen weliswaar de regulerende functie van de organisatiecultuur voorop, maar onderscheiden de cultuur uitdrukkelijk van de structuur, de technologie en de strategieformulering van de organisatie. Zo wordt in deze visie ruimte geschapen voor symbolische verschijnselen, zoals mythen, metaforen, verhalen en rituelen.

In de derde opvatting wordt cultuur als een aspectsysteem beschouwd. Een aspectsysteem vertegenwoordigt een aspect, activiteit of verschijnsel dat eigen is aan alle subsystemen van de organisatie. Voorbeelden van aspectsystemen zijn besturing en informatisering (Frissen, 1986: p. 541). Frissen stelt dat in deze opvatting cultuur een dimensie is van alle structuren en processen binnen de organisatie. Alle subsystemen hebben een culturele dimensie. Volgens hem is de culturele betekenis van alle organisatieverschijnselen eigen aan die verschijnselen, omdat zij culturele artefacten zijn die niet per se worden ontleend aan het culturele subsysteem van de organisatie.

Tenslotte kan de organisatie zelf als een cultureel verschijnsel worden beschouwd. Organisaties zijn in deze visie zelf een aspect van cultuur. Cultuur is een centraal kenmerk van maatschappelijke processen in het algemeen en dus ook van organisaties. Cultuur is niet alleen een subsysteem en evenmin alleen een aspectsysteem, maar de factor die alle handelingen en structuren bepaalt. Organisatiecultuur is daarom geen adequaat begrip meer, maar blijft wel van belang om deelaspecten binnen de organisatie te verklaren. Frissen noemt als voorbeelden mythen, rituelen, ritualisering en symbolen. Volgens hem wordt in deze visie ook meer teruggegrepen op de cultuursociologie en de antropologie. Cultuur is dan geen contingentiefactor maar een determinerende factor die de organisatie overstijgt.

Frissen (1986: pp. 542-543) besluit zijn overzicht van de verschillende benaderingen van organisatiecultuur met een aantal belangrijke conclusies. Cultuur zou een betekenis moeten krijgen in 
de verbinding van traditionele macro- en micro-analyses van organisaties. Elk van de vier benaderingen biedt ook interessante gezichtspunten voor empirisch onderzoek. De vier benaderingen sluiten elkaar ook niet uit maar vullen elkaar juist aan. Ten slotte kan de vierdeling als onderzoekstrategie worden gebruikt. Cultuur als contingentiefactor levert een eerste inzicht op in de culturele aspecten van de organisatie. Via een beschrijving van het culturele subsysteem van de organisatie kan de worteling van de cultuur als contingentiefactor in de organisatie zichtbaar worden gemaakt. Daarna kan worden onderzocht hoe alle organisatieverschijnselen door dit subsysteem worden beïnvloed en een culturele dimensie krijgen (cultuur als aspectsysteem). Ten slotte kan de organisatie als geheel als een cultureel verschijnsel worden beschouwd.

Op deze wijze wordt wel een verdienstelijke aanzet tot een onderzoekprogramma geformuleerd, maar empirisch onderzoek dat een en ander kan bevestigen of ontkrachten ontbreekt tot dusver volledig. Wel hebben wij hierboven duidelijk gemaakt dat de bureaucratische organisatiestructuur gepaard gaat met een bijbehorende specifieke organisatiecultuur. Vooral in de psychologische bureaucratiebenadering wordt de organisatieculturele factor benadrukt, maar ook in de andere bureaucratiebenaderingen wordt aandacht gevraagd voor het belang van de organisatiecultuur in bureaucratische organisaties. Pogingen tot verandering en hervorming van bureaucratische organisaties dienen zich daarom niet te beperken tot het aanpakken van bureaucratische structuren, maar zouden ook de organisatieculturele dimensie in beschouwing moeten nemen. Het succes van organisationele hervormingen wordt immers mede door de culturele factor bepaald. Eerder in dit handboek hebben wij gezien dat zulks geldt voor zowel overheidsorganisaties in de publieke sector (hoofdstuk B0500) als voor bedrijfsorganisaties in de particuliere sector (hoofdstuk B0400).

\section{Veranderingen bij de overheid}

Laten wij op dit punt gekomen eens bezien, welke veranderingen in de bureaucratie en in de organisatiecultuur van overheden en van ondernemingen zich de laatste jaren hebben voorgedaan hebben dan wel momenteel voordoen. Daarbij wordt een vergelijkend perspectief gehanteerd tussen overheid en onderneming. Wij beginnen met veranderingen in de overheidssector (zie ook Kickert, 1993; Van Mierlo, 1992; 1993a; 1993b; Ringeling, 1993).

Vooral sedert de jaren zeventig wordt binnen de overheid (politieke sfeer en openbaar bestuur) maar ook daarbuiten (de samenleving en het bedrijfsleven) in toenemende mate geklaagd over de verregaande bureaucratisering van het ambtelijk apparaat. Die bureaucratisering is echter, zoals wij al zagen, een algemeen maatschappelijk verschijnsel en vormt naar veler mening ook onderdeel van de crisis van de verzorgingsstaat (zie ook Van Mierlo, 1988b: pp. 13-17). Het openbaar bestuur is echter extra vatbaar voor het bureaucratiseringsverschijnsel, onder meer vanwege de traditionele dominantie van de bureaucratische organisatievorm in deze sector. Overheid en bureaucratie worden dan ook vaak in één adem genoemd. De overheidssector wordt zelfs geteisterd door bureaucratisme, dat wil zeggen dat het ambtelijk gedrag binnen de bureaucratie disfunctionele, pathologische en afwijkende vormen krijgt (Van Braam, 1986: p. 219). Dat komt tot uiting komt in ambtenarij en fonctionarisme.

Een aardige illustratie van die problemen bieden Kickert en Snellen (1986) in hun artikel over het ambtelijk apparaat. Wij lichten uit hun betoog over de beruchte 'parafencultuur' bij de overheid de volgende passages. Parafen zijn initialen die worden geplaatst op stukken om daarmee instemming te betuigen of opmerkingen of veranderingen te waarmerken. In de ambtenarij ken men twee soorten parafen: voorparafen en medeparafen. Een voorparaaf is een paraaf in de hiërarchische lijn. Een stuk gemaakt door een medewerker legt (bijvoorbeeld op een departement) de volgende weg af: bureauhoofd, afdelingshoofd, directeur, directeur-generaal, secretaris-generaal, minister. De top van de hiërarchie parafeert met een eigen kleur, zodat direct zichtbaar is welke opmerkingen van dat niveau komen. Een medeparaaf daarentegen komt niet uit de hiërarchische lijn, maar is een paraaf vanuit de zijlijn, dus van een nevengeschikte medewerker, bureauhoofd, afdelingshoofd, enzovoorts. Als nu op een beleidsstuk niet alle vereiste voor- en medeparafen zijn gezet komt het niet verder, komt het zeker niet bij de top van het departement en gaat het al helemaal niet naar buiten. Lang niet alle stukken die een departement verlaten, komen echter onder de ogen van de minister. Dat is fysiek onmogelijk, al is hij wel voor alle stukken politiek verantwoordelijk. Via welk niveau een stuk het departement wel verlaat en dus extern effect kan sorteren, is afhankelijk van het verleende mandaat. Degene die bevoegd is namens de minister te tekenen, heeft de eindparaaf. Het recht van paraaf is daarmee een partieel vetorecht: zonder de vereiste parafen wordt het stuk niet op het volgende hiërarchische niveau en behandeling genomen en stokt dus 
de besluitvorming. Het toezicht op het aanwezig zijn van de vereiste parafen wordt uitgeoefend door het bureau van de secretaris-generaal en wordt op het departement van onderwijs en wetenschappen heel fraai de voorwas genoemd. De voorparaaf is relatief onproblematisch: de hiërarchisch bovengeplaatste beslist, en dat is in een bureaucratie een normale en ook juiste gang van zaken. De medeparaaf kan echter uitdraaien op een obstructie van jewelste.

Departementen en afdelingen hebben niet zelden tegengestelde belangen en oefenen hindermacht op elkaar uit door zo'n medeparaaf te weigeren of het plaatsen ervan te vertragen, dan wel daaraan voorwaarden te verbinden. De strijd om wie wel en wie niet een bepaald stuk moet paraferen, kan daarom van groot (bureau-)politiek belang zijn (Kickert en Snellen, 1986: p. 259). Dat kan een goede belangenafweging waarin alle relevante aspecten worden meegenomen bevorderen, maar ook - en dat gebeurt niet zelden - tot ontsporingen en geweldige vertragingen aanleiding geven. Daarvan zijn krasse staaltjes bekend. Vandaar dat de roep om een beleid tegen bureaucratisme (Hoogerwerf, 1985) steeds luider klinkt.

Daartoe zijn ook allerlei aanzetten gedaan. In dit verband moet zeker het grootschalige en langlopende VONK-project (Verantwoordelijk, Ondernemend, Klantgericht) van de gemeente Groningen worden genoemd. Een project waarvan de uitvoerders als antwoord op de vraag "En, lukt het een beetje?" zeggen steevast te antwoorden: "In ieder geval een beetje" (Pauka en Zunderdorp, 1988: p. 101). Het aangrijpingspunt in het VONK-project, waarvan op dit moment nog onduidelijk is of het werkelijk een fundamentele keer ten goede heeft bewerkstelligd en waar wij om die reden verder niet op ingaan, is de ambtelijke en politieke cultuur. Dat ligt zeer voor de hand, maar is tegelijkertijd ook zeer problematisch.

Managers onder druk grijpen naar handelwijzen waarmee zij vertrouwd zijn, zonder deze in al zijn consequenties te doordenken. In een organisatie met een bureaucratische traditie is dan de natuurlijke neiging om naar bureaucratische middelen te grijpen om de bureaucratie te bestrijden, althans te beheersen. Men doet dan voorstellen ter versterking van de externe controle op de organisatie, zoals verbetering van de bewerktuiging van het parlement als tegenmacht, meer bemoeienis van de kamerleden met de departementen, strakkere leidinggeving door de ministers, de instelling van het instituut ombudsman en invoering van systematische beleidsanalyse. Van den Doel en Van Velthoven (1990: pp. 191-192) stellen echter dat het effect van al deze maatregelen niet anders dan gering kan zijn, omdat de feitelijke omspanning van de politieke leiding de norm die aanvaardbaar is voor een effectieve bevelvoering (de 'span of control') reeds lang overschreden heeft. Als deze constatering klopt voor de overheid, en daarvoor bestaan tal van aanwijzingen, zal zij zeker ook voor veel ondernemingen opgaan. Van den Doel en Van Velthoven hebben het alleen over de overheid en trekken de conclusie dat het fundament van de ambtelijke macht moet worden geslecht om politieke greep op de bureaucratie te krijgen. Zij houden daartoe een pleidooi voor meer interne controle van de bureaucratie via invoering van het model van ambtenarenzelfbestuur. Van den Doel lanceerde dit model al bijna twintig jaar eerder in zijn Nijmeegse oratie van 1973. Het idee werd met veel scepsis ontvangen, maar zo veel jaar later heeft hij het genoegen om te zien dat allerlei arrangementen van ambtelijk zelfbeheer in het openbaar bestuur worden ingevoerd, die min of meer zijn te herleiden tot de logische grondvorm van ambtenarenzelfbestuur.

In de jaren tachtig wordt met name via de zogeheten 'grote operaties' (zie Van Nispen en Noordhoek, 1986) geprobeerd de publieke sector te saneren en beter te beheersen. Deze grote operaties in de publieke sector zijn uitvoerig behandeld in hoofdstuk B0500 van dit handboek. Zij werden vooral ter hand gevoerd ter bestrijding van de economische crisis. Zij omvatten: de reorganisatie van de rijksdienst, de min-twee procent operatie (vermindering van het aantal ambtenaren), de decentralisatie, de deregulering, de privatisering en de heroverwegingsoperatie. In het kader van deze operaties, waarvan sommige sneller en met meer succes werden doorgevoerd dan andere, zijn inmiddels een aantal maatregelen genomen die zijn te kenschetsen als pogingen tot debureaucratisering van het ambtelijk apparaat van de overheid, omdat zij de (vaak veel te lange) hiërarchische lijnen van de openbare bestuursorganisatie beogen te doorbreken (zie Rosenthal e.a., 1987: pp. 124-129).

Ten eerste werden projectorganisaties in het openbaar bestuur beproefd, zowel voor grote intradepartementale als interdepartementale operaties. Volgens de commissie-Vonhoff (1980) zou deze benadering moeten steunen op projectgewijze toedeling van portefeuilles aan projectministers en staatssecretarissen om grootschalige problemen effectiever aan te pakken. De projectorganisatie is echter sterk afhankelijk van de medewerking van de reeds bestaande organisaties, die in de overheidsbureaucratie natuurlijk niet snel hun machtsposities zullen opgeven. Van de plannen van de commissie-Vonhoff is dan ook weinig terecht gekomen. 
Een ander middel is de matrixorganisatie. In veel overheidsdiensten werden lijn-stafverhoudingen in een matrixstructuur georganiseerd, bijvoorbeeld binnen het ministerie van defensie. Het voordeel is dat de matrixorganisatie wordt verweven met de bureaucratische lijn. Een nadeel is echter dat de eenheid van bevelvoering wordt doorbroken en dat functionele en operationele bazen tegen elkaar kunnen worden uitgespeeld.

Intern ambtenarenzelfbestuur is een derde middel. Het model van ambtenarenzelfbestuur omvat nevenschikking van de ambtenaren, besluitvorming over het beleid bij meerderheid van stemmen, het vaststellen van de begroting van de organisatieonderdelen door politieke gezagsdragers na onderhandelingen met de afdelingen of bureaus, en vrije concurrentie tussen organisatieonderdelen bij het dingen naar opdrachten. Op deze wijze wordt volgens Van den Doel en Van Velthoven (1990), die dit model op basis van de economische bureaucratietheorie theoretisch hebben uitgewerkt, het fundament van de ambtelijke macht geslecht. Praktisering van het model van ambtenarenzelfbestuur stuit evenwel op grote invoeringsproblemen, om over de staatsrechtelijke bezwaren nog maar te zwijgen. Het model heeft echter wel de gedachtenvorming aangescherpt bij het uitproberen van middelen ter verbetering van de bedrijfsen beleidsvoering bij de overheid, zoals zelfbeheer en contractmanagement.

Bij zelfbeheer gaat het om de delegatie van budgettaire verantwoordelijkheid aan organisatieonderdelen in het openbaar bestuur. In ruil daarvoor worden prestatieverplichtingen met de betrokken onderdelen overeen gekomen. De wijze waarop die prestaties tot stand komen is echter zaak van de betrokken onderdelen zelf. Relatering van budgettaire middelen aan de te leveren prestatie maakt een reëlere controle mogelijk. Contractmanagement sluit hierbij aan. Hier betreft het afspraken over bevoegdheden, budgetten, personeelsformatie en te leveren prestaties. Het kan gaan om convenanten tussen gezagsdragers en ambtelijke diensten of om contracten tussen lijn- en stafonderdelen. De leidende gedachte in zelfbeheer en contractmanagement is dat eigen verantwoordelijkheid van organisatieonderdelen de wil tot presteren en de efficiency zal vergroten. De experimenten die daarmee in het openbaar bestuur worden gehouden hebben echter nog weinig resultaat opgeleverd.

Van een doorslaand succes kan nog (steeds) niet kan worden gesproken. Met name het ministerie van binnenlandse zaken heeft veel energie gestopt in deze pogingen tot debureaucratisering. Er verscheen zelfs op gezette tijden een informatiekrant over deze veranderingen, 'Torentje in verandering' geheten. Ter illustratie grasduinen wij wat in een aflevering ('Torentje in verandering', nr. 6, november 1989). Tussen de regels van de peptalk door (Contractmanagement werkt! Hokjesgeest verdwijnt! Medewerkers zijn weer trots op FEZ!) kan men daarin lezen waar de schoen op voorspelbare wijze wringt. Zo zijn er afdelingen 'waar de keuze voor decentraliseren' nog niet is gemaakt (een eufemisme voor ambtelijke weerstand tegen het opgeven van machtsposities). Ook heeft 'de noodzakelijke aanpak van boven naar beneden (....) wel tot gevolg dat zelfbeheer tot nu toe vooral in de "hogere regionen" van het departement leeft'. Met andere woorden; de ontbureaucratisering wordt op perfect bureaucratische wijze van bovenaf opgelegd en blijkbaar geloven de middelbare en lagere ambtenaren - en daar zijn er de meeste van - er nog niet of nauwelijks in. Dan blijken er 'onbedoelde' (en, voegen wij daar aan toe, typisch bureaucratische) neveneffecten te zijn: 'we dreigen in papier ten onder te gaan' en 'er is een groei van het aantal stafachtige functies'. Voorts is men op het probleem gestoten van het primaat van de politiek ('u kunt op elk moment geconfronteerd worden met verlangens van uw minister die buiten het met u gesloten contract omgaan') en heeft een externe adviseur ontdekt dat het moeilijk is om helderheid te verkrijgen over wie bij de overheid waarvoor nu precies verantwoordelijk is. En ook dat het bij de overheid buitengewoon lastig is om de output, het produkt te formuleren, laat staan te kwantificeren, terwijl dat nu juist een noodzakelijke voorwaarde is om een eenduidig contract op te kunnen stellen. De kern van het probleem treffen wij echter ook in het blaadje aan: 'Contractmanagement houdt een cultuurverandering in (....)'. Inderdaad een waarheid als en koe. De vraag is evenwel wederom, of er op dat punt veel vooruitgang is geboekt.

In elk geval heeft zich in de jaren tachtig wel verbaal of terminologisch een fundamentele omslag in de organisatiecultuur van de overheid voorgedaan. Spreken over 'bedrijfsvoering' en over verbetering van die bedrijfs- en ook de beleidsvoering is niet langer taboe. Bedrijfsmatig werken wordt als expliciete doelstelling gehanteerd, waarbij de bedrijfsvoering van ondernemingen als voorbeeld en ideaal geldt. Zo heet een oud vakgebied als openbare financiën tegenwoordig ook wel economie van de publieke sector en noemen sommigen bestuurskunde de bedrijfskunde van het openbaar bestuur. Managementtechnieken als 'overhead value analysis', die in het bedrijfsleven gemeengoed zijn, worden ook aanbevolen voor het openbaar bestuur. Klantgerichtheid, marktoriëntatie, prestatiegerichtheid en efficiencyverbetering zijn centrale thema's in de discussie over openbare dienstverlening geworden. Het openbaar bestuur wordt steeds meer gezien als een bedrijf dat weliswaar bijzondere goederen en diensten 
produceert (zogeheten publieke of collectieve goederen en diensten, waarvan de voorziening aan het marktmechanisme is onttrokken maar om niet plaats heeft via het budgetmechanisme, aan welke beslissing technische, economische of politieke motieven ten grondslag liggen), maar dat niettemin als een 'bedrijf' kan worden bestuurd.

De organisatiecultuur van de overheid is in de tweede helft van de jaren tachtig verbaal dus veel 'bedrijfsmatiger' geworden, maar of dat ook in het feitelijk overheidsfunctioneren zijn weerslag heeft gevonden en zo ja, of dat beklijven zal, is ondanks alle rethoriek nog onduidelijk.

\section{Veranderingen bij het bedrijfsleven}

Ook in het bedrijfsleven is sedert de jaren zestig sprake van een gestaag bureaucratiseringsproces. Vooral de zeer grote, multinationale bedrijven worden er door getroffen. Binnenskamers is de opvatting dat de bureaucratie bij bedrijven als Shell, Philips, Unilever, Hoogovens en AKZO minstens zo groot is als bij de overheid algemeen aanvaard. Eerder dan in de overheidssector is het probleem echter ook als zodanig onderkend en zijn maatregelen getroffen. Het bedrijfsleven werd daartoe ook wel gedwongen door de economische crisis waardoor het in de jaren zeventig werd getroffen.

De pogingen tot debureaucratisering werden er wel eerder ondernomen dan in de overheidssector, maar zij hadden dezelfde bedoeling, te weten: een beleid tegen bureaucratisme. De middelen die werden beproefd waren ook nagenoeg dezelfde als bij de overheid. Men zou kunnen zeggen dat deze middelen tien jaar na dato door de overheid werden overgenomen van het bedrijfsleven. Project- en matrixorganisaties zijn organisatievormen die in de leer der interne (bedrijfs-)organisatie ontwikkeld zijn (zie bijvoorbeeld de vierde druk van het bekende handboek van Van der Schroeff, 1968). Zij worden in de jaren zeventig in vooral grote bedrijven, die het meest door bureaucratisering worden geplaagd, toegepast,evenals diverse vormen van zelfbeheer en contractmanagement. Men spreekt dan ook wel van intern ondernemerschap. In deze grote bedrijven heeft toepassing ervan uiteindelijk geleid tot een zo groot mogelijke verzelfstandiging binnen het moederbedrijf van bedrijfsonderdelen, zoals bijvoorbeeld produktdivisies en 'business units'. Soms werd zelfs de beslissing genomen tot volledige verzelfstandiging van bedrijfsonderdelen, met name waar het conglomeraten van bedrijven betrof die waren ontstaan op de fusiegolf van de jaren zestig maar die in de jaren zeventig de economische crisis niet goed konden doorstaan, mede als gevolg van integratieproblemen. Fusies werden soms weer ongedaan gemaakt, zoals in het geval van Hoogovens dat eerder met het Duitse Hoechst-concern in Estel was opgegaan. In weer andere gevallen werd de beslissing genomen terug te keren tot de 'kernactiviteiten' waarmee het bedrijf ooit was gestart en alle bedrijfsactiviteiten die inmiddels branchevreemd werden bestempeld, af te stoten.

De organisatiecultuur van het bedrijfsleven is ook voorwerp geweest van intensieve pogingen tot verandering. Nieuwe managementstijlen zijn beproefd, soms met veel succes naar soms ook met minder resultaat. In reactie op de Japanse uitdaging heeft men in het bedrijfsleven meer oog gekregen voor de noodzaak van minder hiërarchische managementtechnieken, terwijl ook het belang van de organisatiecultuur naast de (formele) organisatiestructuur van bedrijven is onderkend. Een voorbeeld van een nieuwe managementstijl die door de Japanse concurrentie maar ook de Japanse bedrijfscultuur is geïnspireerd, wordt gepropageerd door de stichting MANS (Management en Arbeid Nieuwe Stijl) en toegepast in bedrijven die bij deze stichting zijn aangesloten, bijvoorbeeld NedCar in Helmond. Daarbij gaat het vooral om kwaliteitsverbetering van de produkten via verhoging van de betrokkenheid van de werknemers bij hun werkzaamheden binnen het bedrijf.

Een tweede verandering in de organisatiecultuur van de bedrijven betreft het langzaam groeiende besef dat ondernemingen niet alleen een bedrijfsverantwoordelijkheid bezitten, maar ook een maatschappelijke verantwoordelijkheid. Met name ten aanzien van de milieuproblematiek begint zich dit af te tekenen. Milieuvriendelijkheid, in het bijzonder van de produkten, is een belangrijke factor geworden in het marketingbeleid van veel ondernemingen (men denke aan het Grüne Punkt-symbool!). Dat is natuurlijk in eerste instantie een verkoopargument en geen idealisme, maar de motieven achter de boodschap hoeven niet verheven te zijn om toch het gedrag en de organisatiecultuur in goede zin te kunnen beïnvloeden. De invloed op de ondernemingscultuur komt overigens van meer kanten. Ondernemers gaan in toenemende mate beseffen dat, of zij dat nu willen of niet, door de algemene maatschappelijke vervlechting bij het ondernemen meer partijen dan alleen de kapitaalverschaffers, werknemers, leveranciers en afnemers betrokken zijn. Andere zulke zelfbenoemde stakeholders zijn overheden, consumentenorganisaties, vakbonden, omwonenden, ja, niet zelden de samenleving at large. Dat vergt het ontwikkelen van een andere visie op de verantwoordelijkheid en de rol van de 
onderneming in de maatschappij. Vooral de Stichting Maatschappij en Onderneming (SMO), gevestigd in Scheveningen, vervult met diverse activiteiten daarin een pioniersrol. Zie bijvoorbeeld de opvallende publikatie Ondernemen in een intelligente economie (De Ridder, 1988).

Dit toegenomen maatschappelijke verantwoordelijkheidsbesef komt ook tot uiting in de rol die vooraanstaande ondernemers in de jaren tachtig zijn gaan spelen in het politieke adviseringscircuit van permanente adviesorganen en ad hoc-adviescommissies. Bekende voorbeelden zijn de commissie-Wagner over het te voeren industriebeleid, de commissie-Oort over de belastinghervorming en de eerste en tweede commissies-Dekker over het technologiebeleid, respectievelijk de hervorming van de gezondheidszorg.

\section{7. 'Corporate Culture'}

De lezer die uit het voorgaande de indruk heeft gekregen dat wij voor wat betreft de cultuur van organisaties vooral beschikken over literatuur die beschouwend en idealistisch maar helaas nauwelijks empirisch van aard is, heeft het bij het rechte eind. Dat geldt a forteriori voor de eventuele cultuurverschillen tussen overheden en ondernemingen. Wel weten wij in vergelijkend opzicht iets over de 'corporate culture' van profit- en non profit-organisaties in Nederland. Antropologen (sic!) deden daar empirisch onderzoek naar, waarvan de bevindingen voor ons onderwerp uiterst relevant zijn.

Corporate culture is een specifiek aspect van de organisatiecultuur, te weten de mate waarin de leden zich vereenzelvigen met de eigen organisatie en voorts een sterke onderlinge cohesie en een sterke geslotenheid ten opzichte van andere organisaties vertonen (Koot et al., 1989: p. 42). Dat (deel-) verschijnsel is, zoals gezegd, wel empirisch onderzocht.

De bedoelde onderzoekers namen twaalf Nederlandse organisaties onder de loep en konden met de resultaten van hun onderzoek twijfel zaaien over het waarheidsgehalte van enkele nog nauwelijks omstreden opvattingen uit de literatuur. Ten eerste de opvatting dat een sterke corporate culture een noodzakelijke voorwaarde is voor een organisatie om succes te kunnen hebben. Dat bleek niet zo te zijn: een organisatie met een zwak ontwikkelde corporate culture kan heel wel succesvol zijn, als zij maar niet onder druk staat. Het onderzoek toonde dat aan met een casus betreffende een gemeente, een paragouvermentele monopolist en een onderneming die te maken had met een zeer willige en snel groeiende markt (Koot et al., 1989: p. 53).

Ten tweede bleek de beperkte maakbaarheid van een corporate culture: als de belangen van verschillende groepen in de organisatie sterk uiteenlopen en er over en weer negatieve beelden bestaan, is alle energie die wordt besteed aan het bewust aankweken van een corporate culture, verspilde moeite. Een organisatiecultuur die gekenmerkt wordt door zekerheid, loyaliteit en controle (de organisatie als een familie, met strenge maar rechtvaardige en zorgzame ouders aan het hoofd), biedt ook geen gunstige voedingsbodem voor het ontstaan van corporate culture. Dat alles bleek bij een koek- en chocoladefabriek, bij de serviceafdeling van een multinational, bij een ziekenhuis, een universiteit en een ministerie (Koot et al., 1989: p. 65).

Een corporate culture kan dus niet goed worden opgelegd aan een organisatie, maar zij ontstaat min of meer van binnen uit. Die uitkomst resulteerde uit het onderzoek bij een drankengroothandel, waar de directie er geen enkele moeite voor deed maar de omstandigheden toevallig wel gunstig waren (gemeenschappelijke herkomst en doelstellingen van het personeel, parallel lopende perceptie van belangen). Daar ontstond wel een sterk wij-tegen-de-anderen-gevoel (Koot et al., 1989: p. 69). Ook de gedachte dat externe druk op de organisatie voor de soms felbegeerde corporate culture ('I want a corporate culture by monday', is een running gag over Amerikaanse managers) kan zorgen, bleek niet altijd houdbaar. Op grond van onderzoek bij een onder druk staande gemeente en een computerbedrijf in het nauw concludeerden de onderzoekers, dat externe druk in elk geval geen voldoende voorwaarde is: er moet blijkbaar aan meer vereisten worden voldaan (Koot et al., 1989: p. 69).

De conclusie die voor onze oogmerken het belangrijkste is, luidt evenwel dat verschillen ten aanzien van het al dan niet (kunnen) hebben van een corporate culture nauwelijks in verband gebracht bleek te kunnen worden met het onderscheid profit versus non-profit. Met andere woorden: op dit punt zullen overheden en ondernemingen door hun overheid- respectievelijk onderneming-zijn alléén nauwelijks verschillen kunnen vertonen. In het betreffende onderzoek wordt aannemelijk gemaakt dat er talloze andere variabelen zijn, interne en externe, die met de specifieke omgeving van de organisatie 
samenhangen, of met haar geschiedenis, en die een zeker zo grote invloed uitoefenen op het al of niet tot stand komen van een corporate culture (Koot et al., 1989: p. 88).

\section{Conclusie}

Keren wij terug naar de centrale vraag: het verschil tussen overheden en ondernemingen voor wat betreft het bureaucratiseringsverschijnsel en hun organisatiecultuur, dan kunnen wij om te beginnen twee mythen doorprikken. Er is ten eerste geen enkele grond voor de mening dat de overheid het alleenvertoningsrecht op bureaucratische uitwassen heeft en het bedrijfsleven geheel vrij van deze smetten zou zijn. Bureaucratisering, en dus ook het voorkomen van ontsporingen, lijkt een algemeen maatschappelijk verschijnsel dat eerder in tamelijk hoge mate een functie van de omvang dan van de soort van de betreffende organisatie is. Het verschil tussen overheden en ondernemingen op dit punt is eerder een verschil in gradatie, in gevoeligheid voor bureaucratisme, en in de snelheid en effectiviteit waarmee pogingen om een halt aan het proces van bureaucratisering toe te roepen, wordt ondernomen.

Ten tweede is er geen reden te vermoeden dat ondernemingen een sterke corporate culture zouden hebben en overheden een zwakke. Het is voorts dubieus of het ontbreken van een corporate culture wel altijd zo erg is en ook of die van bovenaf wel opgelegd kan worden. Dat laatste is misschien vooral een domper voor bureaus die op dat gebied adviseren en trainingen verzorgen.

Voor de organisatiecultuur in brede zin geldt dat wij wel over veel idealistische (zo niet ideologische) beschouwingen beschikken, maar over weinig degelijke theorie, laat staan empirische kennis. Zowel bij de overheid als in het bedrijfsleven lijken belangrijke veranderingen - in elk geval met de mond en op papier beleden - in de organisatiecultuur te hebben plaatsgehad. Het vermoeden is voorts dat overheden en ondernemingen sinds de tweede helft van de jaren tachtig op dit punt naar elkaar toe groeien.

Overheidsorganisaties willen bedrijfsmatiger worden, ondernemingen aanvaarden in toenemende mate een bredere maatschappelijke verantwoordelijkheid. Of er sprake is van een echt toenaderingsproces of zelfs van convergentie tussen beide sectoren, zal evenwel uit empirisch vergelijkend onderzoek moeten blijken. Bij gebrek aan de resultaten van zulk onderzoek zijn min of meer intelligente speculaties en impressies het beste materiaal waarover wij thans kunnen beschikken. 


\section{Literatuur}

Albrow, M, 1970, Bureaucracy, London.

Allison, G.T., 1971, Essence of Decision. Explaining the Cuban missile crisis, Boston.

Baakman, N.A.A. en J.G.A. van Mierlo, 1991, Overheid en Onderneming. Een Inleiding, Groningen.

Berg, E., 1975, Decentralisatie in Drievoud, oratie Erasmus Universiteit Rotterdam, Den Haag.

Braam. A. van, 1986, Leerboek bestuurskunde. A. Tekstboek, Muiderberg.

Doel, J. van den, 1973, Ekonomie en Demokratie in het Staatsbestuur, oratie Katholieke Universiteit Nijmegen, Deventer, herdrukt in W.J. driehuis (red), 1977, Economische Theorie en Economische Politiek in Discussie, Leiden, pp. 325-358.

Doel, J, van den en B.C. van Velthoven, 1990, Democratie en Welvaartstheorie, derde herziene druk, Alphen aan den Rijn.

Downs, A., 1967, Inside bureaucracy, Boston.

Frissen, P., 1986, Organisatiecultuur: een overzicht van benaderingen, in $M$ en $O$, nr. 6, pp. 532-544.

Frissen, P., 1988, Symboliek van politiek, bestuur en beleid. Het werk van Murray Edelman, in A.F.A. Korsten en Th. A. J. Toonen (red.), Bestuurskunde. Hoofdfiguren en Kernthema's, Leiden, pp. 395-410.

Frissen, P.H.A. en J.M. van Westerlaak, 1990, Organisatiecultuur. Van toverwoord tot bruikbaar begrip, Schoonhoven.

Halperin, M., 1974, Bureaucratic Politics and Foreign Policy, Washington D.C.

Hofstede, G.A., 1980, Culture's Consequences, London.

Hofstede, G.A., 1983, The cultural relativity of organizational practices and theories, in Administrative Science Quarterly, pp. 75-89.

Hoogerwerf, A., 1985, Een beleid tegen bureaucratisme, in H.A. van der Heijden en J. Kastelein (red.), Succesen faalfactoren bij bestuurlijke reorganisaties, Groningen, pp. 47-61.

Kickert, W.J.M. (red.), 1993, Veranderingen in management en organisatie bij de rijksoverheid, Alphen aan den Rijn.

Kickert, W.J.M. en I.Th.M. Snellen, 1986, De paraaf in de ambtelijke cultuur, in Bestuurswetenschappen, jaargang 40, nummer 4, pp. 257-272.

Koot, W., et al., 1989, Mythen over corporate culture. Fictie en werkelijkheid van organisatiecultuur in de profit en non-profitsector, Utrecht.

Korsten, A.F.A., F. Kluytmans, T.W.P.M. van der Krogt en A. Sorber (red.), 1991, Overheidsmanagement en de menselijke factor, Congrespublicatie 1991 van de Vereniging voor Bestuurskunde, 's-Gravenhage.

Lammers, C.J., 1983, Organisaties vergelijkenderwijs, Utrecht en Antwerpen.

Maarse, J.A.M., 1988, Planning en uitvoering van overheidsbeleid. Het werk van Renate Mayntz, in A,F.A. Korsten en Th.A.J. Toonen (red.), Bestuurskunde. Hoofdfiguren en Kernthema's, Leiden, pp. 377-393. 
Mierlo, J.G.A. van, 1984, De economische theorie van het politieke proces en de representatieve democratie. Een overzicht van dertig jaar theorievorming en empirisch onderzoek, in Maandschrift Economie, augustus, pp. 256285.

Mierlo, J.G.A. van, 1988a, Ambtelijk gedrag in bureaucratische organisaties. Het werk van Anthony Downs, in A,F.A. Korsten en Th.A.J. Toonen (red.), Bestuurskunde. Hoofdfiguren en Kernthema's, Leiden, pp. 229-253.

Mierlo, J.G.A. van, 1988b, Pressiegroepen in de Nederlandse politiek. Controleren pressie- en belangengroepen Nederland?, 's-Gravenhage.

Mierlo, J.G.A. van, 1992, Ambtelijk ondernemerschap in contacten met klantgroepen en belangengroepen, Research Memorandum RM 92-036, Faculty of Economics and Business Administration, Limburg University, Maastricht, September.

Mierlo, J.G.A. van, 1993a, Ambtelijk ondernemerschap als innovatieve managementstrategie in de publieke sector, Research Memorandum 93-007, Faculty of Economics and Business Administration, Limburg University, Maastricht, February.

Mierlo, J.G.A. van, 1993b, Ambtelijk ondernemerschap in contacten met klantgroepen en belangengroepen, in A.J.G.M. Bekke, F. van Dijk, A.P.M. Schrijvers, N. Wijma en G. Wijnen (red.), Handboek Management in Overheidsorganisaties, Alphen aan den Rijn, pp. A3140-1 -A3140-26.

Mintzberg, H., 1979, The structuring of organisations, Englewood Cliffs N.J.

Mintzberg, H., 1983, Structures in fives: designing effective organisations, Englewood Cliffs N.J.

Niskanen, W.A., 1971, Bureaucracy and representative government, Chicago.

Nispen, F.K.M. en D.P. Noordhoek (red.), 1986, De Grote Operaties. Overheid onder het mes of snijden in eigen vlees?, Deventer.

Pauka, T. en R. Zunderdorp, 1988, De banaan wordt bespreekbaar. Cultuurverandering in ambtelijk en politiek Groningen, s.1.

Peters, Th.J., and R.H. Waterman, 1982, In search of excellence. Lessons from America's best-run companies, New York.

Ridder, W.J. de, 1988, Ondernemen in een intelligente economie, SMO-boek, 's-Gravenhage.

Ringeling, A.B., 1978, Beleidsvrijheid van ambtenaren, Alphen aan den Rijn.

Ringeling, A.B., 1981, Democratie en bureaucratie, in J.J.A. Thomassen (red.), Democratie in theorie en praktijk, Alphen aan den Rijn, pp.

Ringeling, A.B. (red.), 1985, Ambtelijke cultuur en verandering van het openbaar bestuur, Congrespublicatie 1985 van de Vereniging voor Bestuurskunde 's-Gravenhage.

Ringeling, A.B., 1991, Democratie en bureaucratie, in J.J.A. Thomassen (red.), Hedendaagse Democratie, Alphen aan den Rijn, pp. 251-273.

Ringeling, A.B., 1993, Het Imago van de Overheid, 's-Gravenhage.

Rosenthal, U., 1988, Bureaupolitiek en Bureaupolitisme. Om het behoud van een competitief overheidsbestel, oratie Rijksuniversiteit Leiden, Alphen aan den Rijn.

Rosentha1, U., M.P.C.M. van Schendelen en A.B. Ringeling, 1987, Openbaar Bestuur. Organisatie, politieke omgeving en beleid, vierde druk, Alphen aan den Rijn.

Schroeff, H.J. van der, 1968, Leiding en organisatie van het bedrijf, vierde druk, Antwerpen en Amsterdam.

Weber, M., 1972, Gezag en bureaucratie, (red. en vert. A. van Braam), Rotterdam.

Wolfson, D.J., 1988, Publieke Sector en Economische Orde, Groningen. 
Zijderveld, A.C., 1988, Bedrijfscultuur, fantoom en feit, 's-Gravenhage. 